\title{
TRZYDZIEŚCI LAT FUNKCJONOWANIA SAMORZĄDU TERYTORIALNEGO - NAUKA PRAWA ADMINISTRACYJNEGO WOBEC REFORM USTROJOWYCH. ZAGADNIENIA WPROWADZAJĄCE
}

Przeprowadzone w 1990 r. reformy władz lokalnych obejmujące reaktywowanie samorządu terytorialnego i odejście od obowiąującej w PRL zasady jednolitej władzy państwowej stanowiły - co należy podkreślić - jeden z najważniejszych elementów przemian ustrojowych w naszym kraju i były one istotnym elementem działań reformatorskich w ramach realizacji trzech głównych celów transformacji ustrojowej po roku 1989: demokracja, wolny rynek, decentralizacja ${ }^{1}$.

Do 1990 r. ustrój organów władzy lokalnej regulowała przede wszystkim ustawa z 20 lipca 1983 r. o systemie rad narodowych i samorządu terytorialnego ${ }^{2}$. Mimo że w nazwie ustawy użyto terminu „samorząd terytorialny”, nie przewidywała ona istnienia tej instytucji.

Postulat przywrócenia samorządu terytorialnego znalazł się w $1981 \mathrm{r}$. w programie Solidarności i powrócono do niego podczas obrad Okragłego Stołu w 1989 r. Warto zauważyć, że wśród zwolenników i propagatorów tej idei w opozycji antykomunistycznej byli przedstawiciele nauki prawa administracyjnego. Najaktywniejszym i najbardziej znanym administratywistą był Michał Kulesza, który jeszcze w okresie PRL uczestniczył w badaniach nad odbudową samorządu terytorialnego, uzasadniał sensowność decentralizacji ${ }^{3}$. W pierwszej dekadzie funkcjonowania odrodzonego samorządu terytorialnego jego koncepcje miały istotne znaczenie dla ustalenia kierunku reform samorządu terytorialnego ${ }^{4}$.

W 1989 r. prof. Kulesza wchodził w skład zespołu do spraw samorządu podczas rozmów Okragłego Stołu, a następnie był zaangażowany w przygotowywanie projektów reformy samorządowej jako pełnomocnik rządu ds. reformy samorządu terytorialnego. Powołany wówczas zespół ds. stowarzyszeń i samorządu terytorialnego został następnie podzielony na dwa podzespoły: ds. stowarzyszeń oraz ds. samorządu terytorialnego. Wprawdzie zgodność poglądów w niektórych kwestiach dotyczyła np. definicji samorządu terytorialnego,

\footnotetext{
1 Kulesza (2002): 5-34.

2 T.jedn.: Dz. U. 1988, Nr 26, poz. 178.

3 Kulesza (1987). 89.

4 Zob. Kulesza (2008).
} 
to rozbieżności były zbyt duże, stąd na wniosek strony opozycyjno-solidarnościowej przerwano rozmowy i sporządzono protokół końcowy ${ }^{5}$. Podczas obrad słuchano też wystapień ekspertów, w tym profesorów prawa konstytucyjnego i prawa administracyjnego.

Grupa ds. samorządu terytorialnego zakończyła pracę 4 marca 1989 r., czyli w połowie obrad Okragłego Stołu, podpisaniem protokołu rozbieżności. Strona koalicyjno-rządowa przedstawiła stronie przeciwnej propozycje zmian niewykraczających poza te, które były już wcześniej przygotowywane w ramach prac nad nową ustawą o radach narodowych ${ }^{6}$.

$\mathrm{W}$ istocie była to zatem koncepcja przekształceń ewolucyjnych w ramach istniejącego ustroju. W dotychczas przyjmowanym żargonie polityczno-prawniczym oznaczało to zmianę pod wpływem „konstruktywnej krytyki”. Z kolei strona opozycyjno-solidarnościowa zakładała stworzenie całkowicie nowej instytucji, niemieszczącej się w ramach ustroju komunistycznego. Zakładano zatem jednoznaczne odrzucenie starego systemu władz lokalnych. Słowo „odrzucenie" ma tu kluczowe znaczenie, gdyż oznaczało jednoznacznie negatywna ocenę przeszłości (np. Hubert Izdebski pisze o procesie „całkowitej recepcji ustrojowych wzorów radzieckich"), będąca zaprzeczeniem oceny jednoznacznie pozytywnej (wraz z dopuszczalną , konstruktywną krytyka”), formułowanej w oficjalnej nauce ustrojowego prawa administracyjnego do $1989 \mathrm{r}$.

Spotkanie przedstawicieli nauki prawa administracyjnego, którzy występowali jako eksperci po obu stronach Okragłego Stołu, miało symboliczny charakter. Dzisiejsza lektura stenogramów obrad tego zespołu ${ }^{8}$ jest szczególnie interesująca, gdyż pokazuje wyraźnie dramatyzm ówczesnej sytuacji w Polsce z perspektywy nauki ustrojowego prawa administracyjnego. $Z$ jednej strony w wielu ośrodkach akademickich problematyka rad narodowych stanowiła od 40 lat istotną część aktywności naukowej administratywistów i konstytucjonalistów, na uczelniach pracowali specjaliści z zakresu problematyki rad narodowych, pisano monografie, rozprawy, podręczniki, artykuły, doktoraty i habilitacje, a z drugiej - proponowano całkowitą likwidację instytucji rad narodowych jako filaru systemu komunistycznego i zastapienie jej przez restytuowany samorzą terytorialny, który w normalnych warunkach funkcjonował do 1939 r. (okres 1945-1950 to czas jego stopniowej likwidacji).

Oczywiście pojawiały się już w poprzednim okresie nieliczne prace, które wykraczały poza dogmatyczne ramy analiz organizacji i funkcjonowania rad narodowych, np. rozprawy habilitacyjne Michała Kuleszy ${ }^{9}$ i Małgorzaty Stahl ${ }^{10}$, a także prace odnoszace się do analiz modeli zachodnich ${ }^{11}$, w tym często rozpatrywanych $\mathrm{w}$ ujęciu historycznym ${ }^{12}$.

\footnotetext{
5 Olszewski (2007): 94-102; Trembicka (1994): 3-10.

${ }^{6}$ Olszewski (2007): 101.

7 Izdebski (2001): 58 .

8 Stenogramy z posiedzeń Okragłego Stołu (1989).

9 Kulesza (1987).

10 Stahl (1989).

11 Np. Chorąży (1986); Niewiadomski (1988); Łętowski (1984).

12 Np. Izdebski (1976).
} 
Propozycja strony rządowej w 1989 r. sprowadzała się do wizji podejmowania działań korygujących, proponowanych m.in. przez ówczesna, silnie upolitycznioną naukę ustrojowego prawa administracyjnego. Obraz rysowany przez stronę solidarnościową sprowadzał się w zasadzie do ukształtowania sytuacji, w której cały dorobek naukowy stawał się nie tylko nieaktualny, ale wręcz szkodliwy w nowych czasach. Ta druga wizja stała się po roku rzeczywistością.

W tej sytuacji w 1990 r. reforma samorządowa stanowiła jednocześnie potężny wstrząs dla nauki ustrojowego prawa administracyjnego, która utraciła swój dotychczasowy przedmiot badań w postaci problematyki rad narodowych. W jednej chwili do lamusa przeszły setki opracowań, które stały się teraz pracami o wartości jedynie historycznej. Kryzys pogłębiała luka pokoleniowa, gdyż z przyczyn naturalnych zabrakło bezpośredniego wsparcia kadry naukowej obserwującej naocznie funkcjonowanie rzeczywistego samorządu terytorialnego w Polsce, w tym zwłaszcza profesorów aktywnych naukowo do 1939 r.

Wraz ze zmianą Konstytucji 8 marca 1990 r. politycznie obalono w Polsce dogmat o wyższości sowieckich rad narodowych nad burżuazyjnym samorządem terytorialnym. Pogląd taki został powszechnie zaakceptowany w nauce prawa administracyjnego. Od tego czasu nie powstało już żadne opracowanie naukowe uznające walory rad narodowych. Oczywiście odrębnym problemem było przyjmowanie wypracowanej dotąd siatki pojęciowej i pewnych konstrukcji myślowych (nie zawsze w pełni uświadamianych) z dotychczasowych prac o systemie rad narodowych, czy też szerzej: z dorobku nauki prawa administracyjnego $\mathrm{w}$ poprzednim ustroju. W otwartym dyskursie, również publicznym, rady narodowe pojawiały się jednak już wyłącznie jako przykład negatywny. Dotyczyło to zwłaszcza prac nad kolejnymi reformami samorządowymi, podczas których niejednokrotnie formułowano obawy o samodzielność gmin w kontekście „negatywnych doświadczeń” rad narodowych. Pierwszym elementem przemian systemu prawnego w kierunku przywrócenia do życia samorządu było uchwalenie 29 grudnia 1989 r. nowelizacji konstytucji PRL z 22 lipca $1952 \mathrm{r}^{13}$, w wyniku której została zmieniona treść jej art. 5, który od 31 grudnia 1989 r. stanowił, że Rzeczpospolita Polska gwarantuje udział samorządu terytorialnego w sprawowaniu władzy oraz swobodę działalności innych form samorządu. Ustawa z 8 marca 1990 r. o zmianie Konstytucji Rzeczypospolitej Polskiej ${ }^{14}$ przewidziała wprowadzenie w miejsce systemu rad narodowych instytucji samorząu terytorialnego na poziomie gminy.

W praktyce zasadnicze znaczenie miała ustawa z 8 marca 1990 r. o samorządzie terytorialnym ${ }^{15}$ (obecnej - od 1 stycznia 1999 r. - ustawie o samorzadzie gminnym ${ }^{16}$ ), gdyż stała się ona pierwszym aktem ustrojowym nie tylko deklarującym konieczność przywrócenia, ale też z dniem 27 maja 1990 r. realnie reaktywującym samorząd terytorialny w Polsce.

\footnotetext{
${ }_{13}$ Dz. U. 1989, Nr 75, poz. 444.

14 Dz. U. 1990, Nr 16, poz. 94

15 Dz. U. 1990, Nr 16, poz. 95 ze zm.

16 T.jedn.: Dz. U. 2020, poz. 713.
} 
Reaktywowaniu samorządu terytorialnego w 1990 r. towarzyszyły dyskusje i spory wokół koncepcji jego istoty, podstaw ustrojowych i szczegółowych zasad funkcjonowania. Prof. Jerzy Regulski, oceniając szanse i bariery rozwoju samorządu terytorialnego, ujmował problem jako wybór pomiędzy dwiema koncepcjami modelu państwa. W pierwszej koncepcji państwo określa wartości, cele i sposoby zachowań ludzi, czyli państwo wskazuje, jak ludzie maja działać. W drugiej sytuacji państwo ma mieć charakter obywatelski, tzn. państwo ma robić to, czego ludzie chca ${ }^{17}$. Pogląd powyższy obrazuje istotę sporów, które w polskiej nauce prawa administracyjnego obecne są co najmniej od okresu międzywojennego.

Oryginalną spuścizną okresu międzywojennego jest podjęcie w obrębie nauki prawa administracyjnego problemów teoretycznych, które mają charakter szerszy niż typowe analizy w obrębie tej specjalności. Wynika to po części z faktu, że profesorowie prawa administracyjnego zajmowali się również ogólnymi problemami prawa ustrojowego. Wizje samorządu w pracach autorów międzywojennych były zróżnicowane. W szczególności początkowo pod rządami Konstytucji marcowej odnoszono się często do koncepcji naturalistycznoprawnej samorządu terytorialnego. Pomimo pierwotnych znacznych różnic ideowych podstaw samorządu terytorialnego, widocznych w doktrynie lat dwudziestych, z czasem następowało umocnienie się tzw. koncepcji państwowej. Dominacja tej koncepcji wynikała z faktu, że wprawdzie międzywojenna nauka prawa administracyjnego nawiązywała w pewnym stopniu do rozwiązań modelowych zachodniej Europy ${ }^{18}$, ale w przeważającej mierze odnosiła się do rozwiązań krajowych i nawiązywała do przemian ustroju państwa. Stanowiło to w pewnej mierze odzwierciedlenie narastajaccych tendencji centralistycznych w polskim ustawodawstwie zwykłym i konstytucyjnym okresu międzywojennego. W praktyce różnice poglądów zwolenników tej koncepcji były jednak znaczne (obrazował to zwłaszcza spór pomiędzy Jerzym Panejko a Tadeuszem Bigo). $\mathrm{W}$ istocie podstawowym problemem była, i nadal pozostaje, kwestia pojmowania państwa ${ }^{19}$. W XX w. rozpiętość możliwości była w tym zakresie znaczna, stąd te same tezy formułowane na gruncie Konstytucji marcowej i Konstytucji kwietniowej miały często zupełnie inne znaczenie. W najnowszej literaturze przedmiotu interesujące spojrzenie na znaczenie dawnych teorii proponuje Irena Lipowicz w ramach koncepcji „biografii pojęć” ${ }^{20}$. Autorka dowodzi, że tylko niewielka część dawnego dorobku nauki prawa administracyjnego jest obecnie wykorzystywana, mimo jego znacznej aktualności. Wyróżnia też kilka podstawowych watków w rozważaniach ówczesnych autorów: celowe rozproszenie władzy państwowej a związki publicznoprawne (Bigo), samodzielny zarząd osób bezpośrednio zainteresowanych (Aleksander Kroński) czy koncepcja partycypacji oraz uznania roli innowacji społecznych (Stanisław Kasznica) ${ }^{21}$.

\footnotetext{
17 Regulski (2011): 10.

18 Panejko (1934a).

19 Izdebsk (1996): 139-182.

20 Lipowicz (2019): 13-14.

21 Lipowicz (2009): 427-438.
} 
Drugim filarem rozwoju nauki prawa administracyjnego w zakresie problematyki samorządu terytorialnego były od 1990 r. studia i badania prawnoporównawcze. Na uwagę zasługują prace grupy autorów, którzy na początku lat dziewięćdziesiątych wskazywali na europejskie doświadczenia samorządu terytorialnego, w tym: Jana Bocia ${ }^{22}$, Zygmunta Niewiadomskiego ${ }^{23}$, Bogdana Dolnickiego ${ }^{24}$, Jana Jeżewskiego ${ }^{25}$, Ireny Lipowicz ${ }^{26}$, Huberta Izdebskiego ${ }^{27}$ i Zbigniewa Leońskiego ${ }^{28}$.

W 1993 r. nastapiło zakorzenienie rozwiązań krajowego prawa samorządowego w systemie prawa międzynarodowego poprzez ratyfikowanie przez Polskę konwencji międzynarodowej pod nazwą Europejska karta samorzadu lokalnego (Karta), w której szczególnie zaakcentowany został związek pomiędzy samorządem a demokracją oraz określone najważniejsze zasady samorządności, w tym zasadę subsydiarności. Późniejsze rozwiązania konstytucyjne z 1997 r. przyniosły jednoznaczne włączenie Karty do polskiego systemu prawnego i nadanie jej wysokiej pozycji w hierarchii źródeł prawa, w szczególności zasadę jej bezpośredniego stosowania, oraz ustalenie pierwszeństwa stosowania przed ustawami i aktami niższego rzędu. Przyczyniło się to w znaczacy sposób do wzmocnienia wpływu Karty na ustawodawstwo zwykłe i orzecznictwo konstytucyjne ${ }^{29}$.

Reforma nie zakończyła się w 1990 r., gdyż prawo samorządowe charakteryzuje się znaczną dynamiką przemian dotyczących konkretnych rozwiązań, co znajduje swój wyraz w licznych nowelizacjach ustaw samorządowych. Małgorzata Stahl podkreśla, że w gwałtownie rozwijającym i zmieniającym się świecie także ustrój samorządu terytorialnego cechuje dynamika ${ }^{30}$. Z kolei Jerzy Korczak dostrzega konieczność rozpatrywania ewolucyjności prawa samorządowego z perspektywy prawa do dobrej administracji ${ }^{31}$. Podobne stanowisko zają Trybunał Konstytucyjny, przyjmując, że pojęcie decentralizacji poprzez samorząd terytorialny oznacza proces stałego poszerzania uprawnień jednostek terenowej władzy publicznej. Nie jest zatem „jednorazowym przedsięwzięciem organizacyjnym”, lecz „trwałą cechą kultury politycznej państwa zbudowanej na właściwych rozwiąaniach ustawowych, zgodnych z konstytucyjnymi zasadami ustroju państwa"32.

$\mathrm{Na}$ kolejnych kilka lat stabilizację i umocnienie rozwiąań przyjętych w 1990 r. przyniosło uchwalenie tzw. Małej Konstytucji, tj. ustawy konstytucyjnej z 17 października 1992 r. o wzajemnych stosunkach między władza

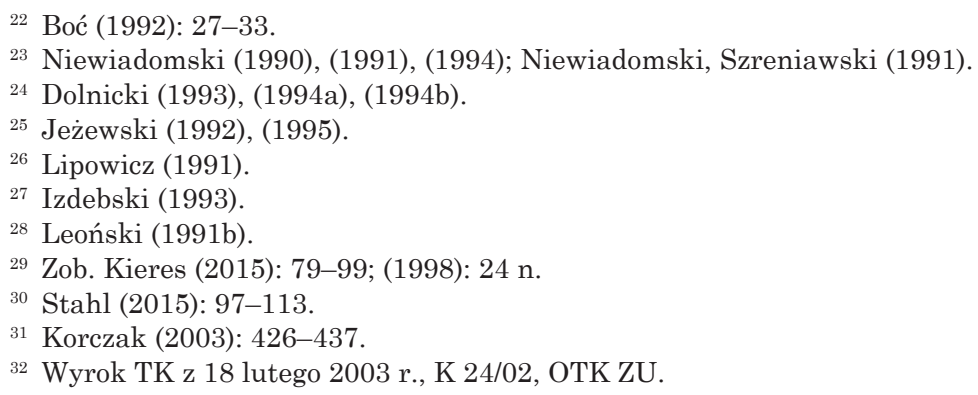


ustawodawczą i wykonawczą RP oraz o samorządzie terytorialnym ${ }^{33}$. Zarysowana w niej koncepcja samorządu terytorialnego nie wykraczała w znaczacy sposób poza rozwiązania znane z ustawy z 8 marca 1990 r. Najważniejszym elementem tego aktu prawnego była konstytucjonalizacja podstawowych zasad ustroju samorządu terytorialnego. Nowością było również dopuszczenie możliwości utworzenia samorządu ponadgminnego.

Powszechnie krytykowaną cechą systemu samorządu terytorialnego w Polsce w latach 1990-1998 była jego struktura, ograniczająca się wyłącznie do stopnia podstawowego. Teresa Rabska, pisząc o pozycji samorządu terytorialnego w Konstytucji, trafnie podkreślała, że jedną z przeszkód na drodze reform stanowi to, że „system prawny obciążony jest konstrukcjami pojęciowymi minionej epoki”" ${ }^{34}$.

Kolejnym reformom towarzyszyła działalność ekspertów z zakresu nauki prawa administracyjnego. W pracach koncepcyjnych nad kształtem reform istotną rolę odegrało kilka ośrodków nauki prawa administracyjnego. W stolicy na pograniczu nauki i praktyki istotną rolę odegrali w charakterze ekspertów profesorowie Uniwersytetu Warszawskiego: Michał Kulesza i Hubert Izdebski. W latach 1997-1999 prof. Kulesza pełnił funkcję sekretarza stanu w Kancelarii Prezesa Rady Ministrów w rządzie Jerzego Buzka. Profesor Izdebski uczestniczył w pracach nad reforma administracji publicznej w latach 1991-1994, 1995-1997, 1998, a także był autorem projektu drugiej ustawy samorzadowej dla miasta stołecznego Warszawy.

W Krakowie w pierwszej połowie lat dziewięćdziesiątych prof. Mirosław Stec z Uniwersytetu Jagiellońskiego był delegatem pełnomocnika rządu odpowiadającym za reformę administracji publicznej w województwie krakowskim $^{35}$, a także wiceministrem w Urzędzie Rady Ministrów. Jako ekspert uczestniczył w przygotowaniu legislacyjnym przepisów dotyczących samorządu terytorialnego $\mathrm{w}$ Konstytucji RP oraz założeń reformy administracyjnej z okresu rządu Buzka.

W poznańskim ośrodku na szczególną uwagę zasługuje działalność prof. Teresy Rabskiej, która w latach 1989-1999 była zaangażowana w działalność legislacyjna jako ekspert parlamentu, pracowała w Zespole ds. Reorganizacji Administracji Publicznej przy Prezesie Rady Ministrów w 1992 r., Radzie ds. Samorządu Terytorialnego przy Prezydencie RP w 1994 r., a także w Radzie ds. Reform Ustrojowych Państwa w 1998 r.

W odniesieniu do poziomu regionalnego istotną rolę odegrały prowadzone w Poznaniu badania nad regionami, zwłaszcza opracowanie dotyczące regionu samorządowego, w którym przedstawiono założenia koncepcji, warianty rozwiązań i propozycje regulacji ${ }^{36}$. Warto przypomnieć również działalność w zakresie doskonalenia prawa samorządowego funkcjonującego w Poznaniu Krajowego Instytutu Badań Samorządowych ${ }^{37}$.

\footnotetext{
${ }^{3}$ Dz. U. Nr 84, poz. 426 ze zm.

34 Rabska (1995): 41.

35 Stec (2015): 23-34; (2020).

36 Kieres, Sowiński (1991).

37 Np. Sowiński (1994); Buczkowski, Sowiński (1994).
} 
Przez wiele lat trwały prace nad koncepcją powiatu samorządowego, która została w dużej mierze przygotowana przez katowicki ośrodek nauki prawa administracyjnego. Istotny wkład w pogłębienie refleksji nad projektami przywrócenia samorządu powiatowego wniosły prace prof. Karola Podgórskiego ${ }^{38}$. Z ośrodkiem tym związana była w tym czasie również prof. Irena Lipowicz, sprawujaca mandat posła i przez długi okres prowadzaca podkomisję sejmową ds. projektu utworzenia samorządu powiatowego. Profesor Lipowicz, jako przewodnicząca sejmowej Komisji Samorządu Terytorialnego i Polityki Regionalnej, odegrała istotną rolę w przygotowaniu reformy w 1998 r., zwłaszcza w odniesieniu do samorządu powiatowego.

Ścisłe łączenie teorii z praktyką widoczne jest w publikacjach pracownika naukowego Uniwersytetu Wrocławskiego prof. Leona Kieresa, który obok działalności akademickiej sprawował szereg funkcji w administracji publicznej. W latach dziewięćdziesiątych był delegatem do Krajowego Sejmiku Samorządu Terytorialnego i członkiem prezydium, a także członkiem Komisji Wspólnej Rządu i Samorządu Terytorialnego. W 1994 r. został powołany do Rady ds. Samorządu Terytorialnego przy Prezydencie RP. Od roku 1997 prof. Kieres był m.in. wiceprzewodniczącym senackiej Komisji Samorządu Terytorialnego i Administracji Państwowej. Jego zdaniem w sytuacji gminy w latach 1990-1998 były partnerem dla administracji rządowej, zarówno centralnej, jak i terenowej, co nie było korzystne dla sprawności funkcjonowania państwa, mierzonej stopniem decentralizacji funkcji publicznych ${ }^{39}$.

Kolejnym ważnym etapem było uchwalenie Konstytucji z 2 kwietnia 1997 r. ${ }^{40}$ Podstawowe zasady ustrojowe samorządu terytorialnego zostały w Konstytucji RP z 1997 r. określone szerzej niż w Małej Konstytucji, w szczególności niektóre zasady ustrojowe, które dotychczas miały wyłącznie rangę ustawową i były sformułowane w ustawie z 1990 r., stały się obecnie zasadami konstytucyjnymi.

Podstawy ustrojowe kolejnych poziomów samorządu terytorialnego, których utworzenie przewidziała Konstytucja z 2 kwietnia 1997 r., określiły odrębne ustawy ustrojowe uchwalone 5 czerwca 1998 r.: ustawa z 5 czerwca 1998 r. o samorządzie powiatowym ${ }^{41}$ i ustawa z 5 czerwca 1998 r. o samorzadzie województwa ${ }^{42}$.

Warto zauważyć, że pomimo skomplikowanych transformacji ustroju działalność samorządu terytorialnego w latach 1990-1998 oceniana jest pozytywnie $^{43}$. Funkcjonujacy od 1999 r. w pełnej strukturze samorząd terytorialny $\mathrm{w}$ następnych dekadach poddawany był również wielu istotnym zmianom. Kolejnym reformom towarzyszyła działalność ekspertów z zakresu nauki prawa administracyjnego. Jednocześnie odnotować należy znaczny rozwój nauki prawa administracyjnego w zakresie problematyki samorządowej. Obecnie

\footnotetext{
38 Podgórski (1993).

${ }^{39}$ Kieres (1994): 13.

${ }^{40}$ Dz. U. Nr 78, poz. 483 ze zm.

41 T.jedn.: Dz. U. 2020, Nr 0, poz. 920.

${ }^{42}$ T.jedn. Dz. U. 2019, Nr 0, poz. 512.

${ }^{43}$ Lipowicz (2015): 15.
} 
badania takie prowadzone są w kilkunastu ośrodkach, corocznie wydawanych jest około stu opracowań książkowych i wielokrotnie więcej artykułów o charakterze ogólnym i specjalistycznym.

Najogólniej ujmując zakres prowadzonych w ostatnich latach badań problematyki samorządu terytorialnego, należy wyróżnić kilka podstawowych nurtów. Pierwszym z nich są badania o charakterze teoretycznym, koncentrujące się na podstawowych problemach genezy i koncepcji samorządu terytorialnego. Do badań takich należy analiza pozycji ustrojowej organów jednostek samorządu terytorialnego ${ }^{44}$. Istotnym elementem jest ukazanie złożoności problematyki prawnej samorządu terytorialnego ${ }^{45}$. Badania te obejmują również problematykę nowych uwarunkowań cywilizacyjnych funkcjonowania samorządu ${ }^{46}$. Ważnym elementem tego nurtu jest analiza z perspektywy nauki prawa administracyjnego konstytucyjnych podstaw ustroju i funkcjonowania samorządu terytorialnego ${ }^{47}$ oraz konstytucyjnego umocowania samorządu terytorialnego ${ }^{48}$, a także samorządu terytorialnego z perspektywy unitarnego charakteru państwa ${ }^{49}$.

Kolejnym kierunkiem badań sa analizy prawnoporównawcze. Badania te dotyczą z reguły zestawienia polskich i zagranicznych doświadczeń ${ }^{50}$. Problematyka samorządowa stanowi istotną część zagadnień europeizacji polskiego prawa administracyjnego ${ }^{51}$.

Dynamicznie rozwijane sa w ostatnich latach badania, które koncentrują się na newralgicznych problemach aktualnego funkcjonowania samorządu terytorialnego, w tym rozwoju publicznoprawnych form współpracy jednostek samorządu terytorialnego ${ }^{52}$ oraz partycypacji społecznej w samorządzie terytorialnym ${ }^{53}$. W obrębie tego nurtu należy wskazać również badania odnoszace się do nowych rozwiązań prawnych, których projekty powstają przy aktywnym udziale doktryny prawa administracyjnego. Znakomitym przykładem pola badawczego w tym zakresie jest problematyka metropolii, $\mathrm{w}$ tym zagadnienia organizacji i funkcjonowania aglomeracji miejskich ${ }^{54}$, koncepcja powiatu metropolitalnego ${ }^{55}$, a także analiza związku metropolitalnego w województwie śląskim ${ }^{56}$ oraz koncepcja i proces powstawania Górnośląsko-Zagłębiowskiej Metropolii ${ }^{57}$.

\footnotetext{
${ }^{44}$ Dolnicki (2019b).

${ }^{45}$ Kasiński (2009); Niewiadomski (2011); Szewczyk (2017); Jaworska-Dębska et al. (2019).

46 Korczak (2018); Lipowicz (2019).

47 Korczak (2012).

48 Stec, Małysa-Sulińska (2018).

49 Stec, Małysa-Sulińska (2019).

50 Dolnicki (2015).

51 Janku et al. (2005); Kowalczyk (2014): 55-65; Lisowski (2014): 29-45; Korczak (2018):

52 Dolnicki (2012); Ziemski, Kiełbus (2020).

53 Dolnicki (2014).

${ }^{54}$ Dolnicki (2018a); Jaworska-Dębska (2017).

55 Dolnicki (2014): 5-17.

${ }^{56}$ Dolnicki, Marchaj (2017b): 5-18.

${ }^{57}$ Dolnicki, Marchaj (2017a): 73-89; Dolnicki (2019a): 206-216.
} $327-350$ 
Po przywróceniu samorządu terytorialnego w 1990 r. nauka prawa administracyjnego przeszła trudną drogę od zanegowania i odrzucenia swojego dorobku z okresu poprzedniego ustroju dotyczacego władz lokalnych do znacznego rozwoju i osiagnięcia pełnej dojrzałości w zakresie refleksji teoretycznej oraz istotnego, stałego poszerzania zakresu analizowanej problematyki. Ponadto cechą charakterystyczną aktywności naukowej najaktywniejszych ośrodków akademickich w zakresie problematyki samorządu terytorialnego jest łączenie dokonań naukowych z działaniami na rzecz praktyki, w tym zwłaszcza działalności w organach samorządu terytorialnego, w parlamencie, w administracji centralnej, w sądownictwie administracyjnym oraz wielostronnej działalności eksperckiej. Widocznym rezultatem silnego oddziaływania doktryny prawa administracyjnego na praktykę legislacyjną stało się znaczące ulepszenie działalności organów państwowych i samorządowych oraz złagodzenie skutków nieudanych rozwiązań.

Janusz Stugocki

Uniwersytet Szczecinski

janusz.slugocki@usz.edu.pl

https://orcid.org/0000-0002-4018-409X

Boć, J. (1992). Autonomia gminna (samorząd gminny) w Belgii. Samorząd Terytorialny 2(3): 27-33. Buczkowski, P., Sowiński, R. (red.) (1994). Samorząd terytorialny drogą do demokracji. Poznań. Chorażzy, K. (1986). Ewolucja pozycji prawnej regionów we Francji. Lublin.

Dolnicki, B. (1993). Nadzór nad samorządem terytorialnym. Katowice.

Dolnicki, B. (1994a). Modele samorządu terytorialnego w Europie i w Polsce. Katowice.

Dolnicki, B. (1994b). Przemiany ustrojowe samorządu gminnego w Europie Zachodniej. Samorząd Terytorialny 4(12): 68-76.

Dolnicki, B. (red.) (2014). Partycypacja społeczna w samorządzie terytorialny. Warszawa.

Dolnicki, B. (red.) (2015). Samorząd terytorialny w Polsce i Portugalii: analiza prawnoporównawcza. Warszawa.

Dolnicki, B. (red.) (2018a). Organizacja i funkcjonowanie aglomeracji miejskich. Warszawa.

Dolnicki, B. (red.) (2019a). Pozycja ustrojowa organów jednostek samorządu terytorialnego. Warszawa.

Dolnicki, B. (2019a). Proces powstawania Górnoślaskko-Zagłębiowskiej Metropolii, [w:] Fenomen prawa administracyjnego: księga jubileuszowa Profesora Jana Zimmermanna. Warszawa: 206-216.

Dolnicki, B., Marchaj, R. (2017a). Górnośląsko-Zagłębiowska Metropolia. Ruch Prawniczy, Ekonomiczny i Socjologiczny 79(3): 73-89.

Dolnicki, B., Marchaj, R. (2017b). Związek metropolitalny w województwie śląskim. Samorząd Terytorialny 7/8: 5-18.

Izdebski, H. (1976). Problemy decentralizacji administracji we Francji XIX wieku. Czasopismo Prawno-Historyczne 78(1): 161-174.

Izdebski, H. (1993). Współczesne modele administracji publicznej. Warszawa.

Izdebski, H. (1996). Samorząd terytorialny w II Rzeczypospolitej [w:] A. Piekara, Z. Niewiadomski, Samorzad terytorialny. Zagadnienia prawne i administracyjne. Wyd. 2. Warszawa: 139-158.

Izdebski, H. (2001). Samorząd terytorialny. Podstawy ustroju i działalność. Warszawa.

Janku, Z., Leoński, Z., Szewczyk, M., Waligórski, M., Wojtczak, K. (red.) (2005). Europeizacja polskiego prawa administracyjnego. Wrocław.

Jaworska-Dębska, B. (2017). O istocie związków metropolitalnych, [w:] B. Jaworska-Dębska (red.), O prawie administracyjnym i administracji. Refleksje. Księga jubileuszowa dedykowana Profesor Małgorzacie Stahl. Łódź: 225-240. 
Jaworska-Dębska, B., Olejniczak-Szałowska, E., Budzisz, R. (red.) (2019). Decentralizacja i centralizacja administracji publicznej: współczesny wymiar w teorii i praktyce. Warszawa.

Jeżewski, J. (1992). Podział kompetencji między samorząd terytorialny a państwo we Francji. Samorząd Terytorialny 2(3): 31-41.

Jeżewski, J. (red.) (1995). Gmina w wybranych państwach Europy Zachodniej. Wrocław.

Kasiński, M. (2009). Monizm i pluralizm władzy lokalnej. Studium prawno-polityczne. Łódź.

Kieres, L. (1994). Problemy ustrojowoprawne samorządu terytorialnego. Samorząd Terytorialny 4(12): 12-20.

Kieres, L. (1998). Analiza zgodności polskiego prawa samorządu terytorialnego z Europejską Kartą Samorządu Terytorialnego. Samorząd Terytorialny 8(9): 3-80.

Kieres, L. (2015). Europejska karta samorządu lokalnego w orzecznictwie Trybunału Konstytucyjnego. Ruch Prawniczy, Ekonomiczny i Socjologiczny 77(3): 77-99.

Kieres, R., Sowiński, R. (red.) (1991). Region samorządowy: założenia koncepcji - warianty rozwiązań - propozycje regulacji. Poznań.

Korczak, J. (2003). Ewolucyjność prawa samorządowego a prawo do dobrej administracji, [w:] Prawo do dobrej administracji. Materiały ze Zjazdu Katedr Prawa i Postępowania Administracyjnego, Warszawa-Dębe, 23-25 września 2002 r. Warszawa: 426-437.

Korczak, J. (2012). Konstytucyjne podstawy struktury i funkcji samorządu terytorialnego, [w:] system prawa administracyjnego. Tom 2: Konstytucyjne podstawy funkcjonowania administracji publicznej, red. R. Hauser, Z. Niewiadomski, A. Wróbel. Warszawa: 177-200.

Korczak, J. (2018). Europejskie wpływy na funkcjonowanie samorządu terytorialnego w Polsce. Acta Universitatis Wratislaviensis. Przegląd Prawa i Administracji 114: 327-350.

Korczak, J. (red.) (2018). Cywilizacja administracji publicznej: księga jubileuszowa z okazji 80-lecia urodzin prof. nadzw. UWr dra hab. Jana Jeżewskiego. Wrocław.

Kowalczyk, B. (2014). Administracyjne prawo porównawcze a europeizacja prawa administracyjnego, [w:] J. Sługocki (red.), Dziesięć lat polskich doświadczeń w Unii Europejskiej: problemy prawnoadministracyjne. Tom 1. Wrocław: 55-65.

Kulesza, M. (1987). Administracyjnoprawne uwarunkowania polityki przestrzennej. Warszawa.

Kulesza, M. (2002). Polskie doświadczenia w zarządzaniu reformą decentralizacyjną. Samorząd Terytorialny 12(9): 5-34.

Kulesza, M. (2008). Budowanie samorządu. Wybór tekstów ze „Wspólnoty” 1990-2007. Warszawa.

Leoński, Z. (1991a). Tradycje samorządu terytorialnego w Polsce. Samorząd Terytorialny 1(3): 39-46.

Leoński, Z. (1991b). Samorząd terytorialny na szczeblu powiatowym w RFN. Samorząd Terytorialny 1(10): 18-23.

Lipowicz, I. (1991). Europejski standard samorządu terytorialnego a ustawodawstwo polskie. Samorząd Terytorialny 1(11/12): 75-83.

Lipowicz, I. (2009). Tradycje i przyszłość samorządu terytorialnego w świetle nauki prawa administracyjnego, [w:] J. Supernat, Między tradycją a przyszłością w nauce prawa administracyjnego - Księga Jubileuszowa z okazji 70. urodzin Profesora Jana Bocia. Wrocław: 427-438.

Lipowicz, I. (2019). Samorzą terytorialny XXI wieku. Warszawa.

Lisowski, P. (2014). Europeizacyjne konotacje instytucji wspólnoty samorządowej w Polsce, [w:] J. Sługocki (red.), Dziesięć lat polskich doświadczeń w Unii Europejskiej: problemy prawnoadministracyjne. Tom 2. Wrocław: 29-45.

Łętowski, J. (red.) (1984). Administracja Republiki Francuskiej. Wrocław.

Niewiadomski, Z. (1988). Samorząd terytorialny w warunkach współczesnego państwa kapitalistycznego. Warszawa.

Niewiadomski, Z. (1990). Samorząd terytorialny w Europie Zachodniej. Warszawa.

Niewiadomski, Z. (1991). Samorząd terytorialny wobec regionalizacji. Samorząd Terytorialny 1(7/8): 42-46.

Niewiadomski, Z. (1994). Samorząd terytorialny w Szwajcarii. Samorząd Terytorialny 4(9): 47-60.

Niewiadomski, Z. (2011). Samorząd terytorialny, [w:] R. Hauser, Z. Niewiadomski, A. Wróbel (red.), System prawa administracyjnego. Tom 6: Podmioty administrujące. Warszawa: 97-160.

Niewiadomski, Z., Szreniawski, J. (1991). Zarys ustroju administracji lokalnej Rzeczypospolitej Polskiej. Lublin. 
Olszewski, P. (2007). Problemy samorządu terytorialnego w obradach Okragłego Stołu. Polityka i Społeczeństwo 4: 94-100.

Panejko, J. (1934). Geneza i podstawy samorządu europejskiego. Wilno.

Podgórski, K. (1993). Zakres działania przyszłego powiatu. Charakter prawny zadań i kompetencji. Samorząd Terytorialny 3(10): 55-60.

Rabska, T. (1995). Pozycja samorządu terytorialnego w Konstytucji. Ruch Prawniczy, Ekonomiczny i Socjologiczny 57(2): 41-56.

Regulski, J. (2011). Szanse i bariery rozwoju samorządu terytorialnego, [w:] Szanse i wyzwania dla rozwoju samorządu terytorialnego w Polsce. Warszawa: 9-16.

Skrzydło-Niżnik, I. (2007). Model ustroju samorządu terytorialnego w Polsce na tle zagadnień ustrojowego prawa administracyjnego. Kraków.

Sowiński, R. (red.) (1994). Doskonalenie prawa samorządowego w pracach Krajowego Sejmiku Samorządu Terytorialnego: II Kongres Samorządu Terytorialnego, Poznań, 13-15 V 1994 r. Poznań.

Stahl, M. (1989). Poszukiwania modelu władzy i administracji lokalnej w Polsce. Łódź.

Stahl, M. (2015). Ewolucja i tendencje rozwojowe samorządu terytorialnego w Polsce - zagadnienia wybrane. Administracja: Teoria, Dydaktyka, Praktyka 3(40): 97-113.

Stec, M. (2015). Pozycja ustrojowa Pełnomocnika Rządu ds. Reformy Samorządu Terytorialnego i jego delegatów (1989-1992). Samorząd Terytorialny 25(3): 23-34.

Stec, M. (2020). Tworzenie samorządu gminnego w 1990 r. z perspektywy Delegata Pełnomocnika Rządu ds. Reformy Samorządu Terytorialnego w województwie miejskim krakowskim. Samorząd Terytorialny 4: 72-81.

Stec, M., Małysa-Sulińska, K. (red.) (2018). Konstytucyjne umocowanie samorządu terytorialnego. Warszawa.

Stec, M., Małysa-Sulińska, K. (red.) (2019). Unitarny charakter państwa a samorząd terytorialny. Warszawa.

Stenogramy z posiedzeń Okragłego Stołu (1989). <https://www.sejm.gov.pl/Sejm8.nsf/stenOkrStol.xsp> [dostęp: 10.09.2020].

Szewczyk, M. (red.) (2017). Z problematyki prawnej samorządu terytorialnego. Księga dla uczczenia 70. Rocznicy urodzin oraz 45. Rocznicy pracy naukowej Profesora Zbigniewa Janku. Poznań.

Trembicka, K. (1994). Okragły Stół w Polsce - koncepcje samorządu terytorialnego. Samorząd Terytorialny 4(4): 3-10.

Ziemski, K., Kiełbus, M. (2020). Ewolucja publicznoprawnych form współpracy jednostek samorządu terytorialnego. Samorząd Terytorialny 4: 82-96.

\section{THIRTY YEARS OF LOCAL SELF-GOVERNMENT FUNCTIONING - THE STUDY OF ADMINISTRATIVE LAW IN THE FACE OF SYSTEMIC REFORMS. INTRODUCTORY ISSUES}

\section{Sum mary}

The reforms carried out in 1990, which included the reactivation of local self-government, constituted one of the most important elements of the systemic transformation in our country. They were also an important element of the reform measures undertaken to implement the three main goals of the political transformation after 1989: democracy, the free market and decentralization. The postulate of restoring local self-government was included in the Solidarity programme in 1981, and it was the subject of renewed focus during the Round Table talks in 1989. Among the supporters and propagators of this idea in the anti-communist opposition were representatives of the study of administrative law, who envisioned the creation of a completely new institution that would not be indebted to the communist regime. It was therefore assumed that the old system of local authorities had been rejected. The self-government reform carried out in 1990 was at the same time a powerful shock to the study of systemic administrative law, which lost its subject of research, namely the issues of national councils, which from then on were treated only in the 
context of 'negative experiences'. The reactivation of the local self-government in 1990 was accompanied by discussions and disputes on the concept of its essence, basic political assumptions and detailed rules of functioning. However, the reform did not come to an end in 1990, as local government law is characterized by a significant dynamic of changes concerning specific solutions, which is reflected in numerous amendments to local government laws. Subsequent reforms were accompanied by the activities of experts in the field of administrative law. At the same time, one should note significant development in the study of administrative law with regard to the consideration of local self-government issues.

Keywords: local self-government; Poland; transformation; self-government reform of 1990 